Monika Borowska1

\title{
Homilia do dzieci - spojrzenie psychologa
}

Artykuł zawiera kilka refleksji psychologa rozwojowego dotyczących psychologicznych aspektów informacyjnej i formacyjnej roli homilii oraz kazań kierowanych do dzieci. Pragmatyka życiowa stawia przed psychologiem zasadnicze pytanie: ja k mów ić, by osiągnąć zamierzony cel? Pytanie to konkretyzuje się w dalszych, dotyczących zasadniczo formalnych, ale także treściowych aspektów homilii i kazań, czyli tego, co jest ich celem, które i jak podane treści są najlepiej przyswajane i rozumiane, a tym samym przekładane na życie religijne dziecka, czym powinien być uzupełniony i wzmocniony przekaz słowny, by mógł spełnić powyższe zadania. Język jest tu oczywiście zagadnieniem centralnym, ale nie wyizolowanym z towarzyszącego mu pozawerbalnego kontekstu całości przekazu.

$1 \quad$ Psycholog, doktor nauk humanistycznych, adiunkt w Katedrze Psychologii Instytutu Nauk o Rodzinie Uniwersytetu Papieskiego Jana Pawła II w Krakowie. Prowadzi prace w zakresie psychologicznej operacjonalizacji zadań rozwojowych realizowanych w rodzinie $\mathrm{z}$ uwzględnieniem regulacyjnej funkcji religijności (monika.borowska@gmail.com). 
Psychologiczna analiza kazań i homilii dla dzieci uwzględnia więc dwa zasadnicze cele. Po pierwsze pozwala poznawać i wyjaśniać, a tym samym ustalać, określać i kontrolować zasadnicze ich wymogi formalne. Może też jednak spełniać rolę trudniejszą i życiowo bardziej doniosłą - badać, a tym samym określać i oceniać przydatność rozwojową (rozumianą jako osiąganie wyższych i lepszych jakości w danej sferze życia) czegoś, co pomaga uformować w dziecku konstrukty, które później pomogą autonomicznie realizować znaczące i ważne, ale jednak trudne formy aktywności życiowej. Mowa tu o formowaniu autonomicznej drogi dochodzenia do wyższych form aktywności religijnej, a tym samym do tych osobistych wartości i znaczeń, które w toku osobniczego rozwoju mogą (ale nie muszą) zostać świadomie wybrane i skonstruowane. Psycholog rozwojowy powie, że takiego wyboru i takich realizacji człowiek najpewniej nie będzie umiał dokonać, jeżeli nie pojawią się wcześniejsze doświadczenia, a na ich podstawie nie zrealizują się dalsze konstrukcje poznawcze uzasadniające te autonomiczne wybory: nie można bowiem wybrać z przekonaniem (a więc z uzasadnieniem) czegoś, czego się nie doświadczyło i czego się nie zna i nie rozumie.

I w ten właśnie układ uwarunkowań rozwoju religijnego wpisują się kazania i homilie dla dzieci jako jedna z pozadomowych form religijnego wychowania dziecka.

Pojawiają się więc kolejne pytania: co chcemy uzyskać, głosząc homilie i kazania dla dzieci i czym dla dziecka jest lub ma być takie doświadczenie? A także czy dla dziecka kazanie i homilia to tylko przekaz słowny? A skoro słowo, to czy tylko ono samo, czy też istotny jest kontekst jego podania? I dalej: kim jest dziecko jako odbiorca homilii i kazań i jakie są specyficzne cechy jego rozwoju, które winny określać formę przekazu treści religijnych? Czy chodzi tu tylko o dostosowanie 
języka do możliwości poznawczych i językowych odbiorcy, czy też jest to wieloelementowy przekaz, którego wszystkie składowe stanowią dla dziecka swoiste i całościowe doświadczenie religijne, a więc w całości muszą być na jego poziomie „przyswajalne"? Jakie winny więc być cechy tego przekazu, a także cechy samego przekazującego? I na końcu pytania o cele homilii i kazań dla dzieci: czy zasadniczo informacja i perswazja czy raczej całościowe doświadczenie formujące?

\section{Dzieciństwo a rozwój religijności człowieka w odniesieniu do poznawczo-rozwojowej koncepcji Czesława Walesy}

Mówiąc o dziecku jako o istocie religijnej czy raczej mogącej się stawać istotą religijną, napotykamy sympatyczny paradoks: dziecko jest - jak wiadomo - na wcześniejszym i tym samym mniej doskonałym niż u człowieka dorosłego poziomie rozwoju poznawczego (czyli: rozumiem, wyjaśniam, uzasadniam), poznawczo-emocjonalnego (czyli: czuję, ale też wiem, co czuję, nazywam to, kontroluję) i moralno-społecznego (świadomie działam i wybieram, wiem, jak należy postępować, po co i dlaczego). Mimo to jednak powszechnie znana jest wciąż powtarzana zachęta: Bądźcie ufni jak dzieci, czy też: Przyjmijcie wobec Boga postawę dziecka. Można więc przez to rozumieć, że dzieciństwo ma jakieś szczególne, istotne dla formacji wewnętrznej cechy. W psychologicznym rozumieniu można przyjąć, że cechą tą jest ufność (związana bezpośrednio z poczuciem bezpieczeństwa i nieobarczona nadmiarem doświadczenia lub też pozwalająca ignorować jego nadmiar i jakość) oraz umożliwiająca otwarcie się i bycie gotowym na nowe doświadczanie ze wspomagającym udziałem Kogoś 
Znaczącego (jest on najczęściej dawcą tego doświadczenia lub w nim pośredniczy). W konsekwencji mamy więc gotowość do nowego doświadczania i działania.

Jak można przypuszczać, to właśnie odnosi do tych pożądanych cech dzieciństwa, które - jak już wspomniano - są szczególnie korzystne dla kształtowania się autentycznej religijności.

Jak wiemy, w sensie rozwojowym dziecko to nie mniej wartościowy dorosły, a skończony człowiek na takim lub innym etapie rozwojowych konstrukcji (stanowi je swoista psychiczna jakość, której pełna realizacja warunkuje kolejne konstrukcje w rozwoju; powiemy więc: pełny i skończony 5-, 6-, 7-latek itd.). Dziecko nie jest więc mniej wartościowym odbiorcą, do którego poziomu trzeba się zniżyć, ale raczej odrębną jakością, którą trzeba znać i rozumieć, jeżeli chce się do niego mówić w celu przekazu i wymiany różnego rodzaju dóbr, np. wiadomości, informacji, uzasadnień, argumentów, itp. Wydaje się, że winno to być szczególnie uwzględniane w wychowaniu religijnym dziecka.

W rozumieniu dziecka i dzieciństwa jako odrębnej i znaczącej jakości w rozwoju religijności człowieka można dostrzec szczególną przydatność poznawczo-rozwojowej koncepcji rozwoju religijności Czesława Walesy² - chyba najbardziej znaczącego polskiego autorytetu w tej dziedzinie wiedzy. W jego koncepcji religijność traktowana jest jako forma aktywności ludzkiej podlegająca naturalnym prawom rozwoju i rozumiana jako stawanie się, konstruowanie. Koncepcja uwzględnia też w sposób oczywisty drogi dochodzenia do interesujących nas form aktywności (czyli czynniki i mechanizmy tych konstrukcji) - a co za tym idzie, umożliwia kontrolowanie tego rozwoju.

Czesław Walesa, zakorzeniając swą koncepcję w poznawczych orientacjach w psychologii, podnosi znaczenie autonomii

2 Cz. Walesa, Rozwój religijności człowieka, t. 1: Dziecko, Lublin 2005. 
w rozwoju, którą można rozumieć jako efekt wcześniejszych konstrukcji niejako do niej doprowadzających. Zasadnicze elementy tych konstrukcji to, najogólniej mówiąc, pierwsza 1/3 życia, a więc podstawowe konstrukcje psychiczne, psychofizyczne, psychospołecznego dla kolejnych 2/3 życia, traktowanych jako etap rozwoju potencjalnych autonomii, które są w znacznym stopniu efektem owych konstrukcji wcześniejszych. Dochodzenie do religijności człowieka dorosłego (podobnie jak kształtowanie każdej innej formy aktywności) jest tu konstrukcją etapową - każdy etap to inna jakość. Prawa i zasady tych etapów są takie same dla wszystkich i przebiegają w tej samej kolejności - można więc mówić o specyfice okresów rozwojowych w rozwoju religijności człowieka.

Zasadniczym regulatorem ludzkiej aktywności jest tu poznanie. Poznanie czyli to, jak człowiek (lub człowiek, który aktualnie jest dzieckiem) postrzega, rozumie i uzasadnia doświadczaną przez siebie rzeczywistość, a także siebie samego. Owo poznanie (a zasadniczo etap jego rozwoju) strukturalizuje inne sfery funkcjonowania człowieka - jego język, moralność, działanie, religijność.

Koncepcja ta, przyjmując aktywny model rozwoju, podkreśla kluczowe znaczenie dla rozwoju człowieka także jego aktywności własnej i jego działania (rozumianego nie tylko czysto wykonawczo, lecz raczej jako w ogóle aktywnego stosunku do rzeczywistości, czego przykładem jest np. samodzielne wnioskowanie, wyobrażanie, przemyślenie). Bez aktywności własnej na rzeczywistości materialnej, symbolicznej i pojęciowej nie ma postępu w ramach kolejnych konstrukcji poznawczych (postęp w rozwoju poznawczym nie jest biernym nabywaniem informacji).

Podkreślenie znaczenia aktywności własnej, otwarcia się na doświadczenie oraz gotowości do działania (jako znaczących dynamizmów w rozwoju) uzasadnia istotność tej koncepcji 
w psychologicznej analizie rozwoju religijności człowieka, rozumianego jako konstrukcja etapowa i potencjalna w rozwoju już od wczesnych etapów życia - a będącej, zgodnie z definicją Walesy, osobową i pozytywną relacją z Bogiem ${ }^{3}$, czyli w sensie psychologicznym jedną z form aktywności człowieka.

Warto zaznaczyć, że koncepcja Walesy jest na gruncie polskim najbardziej znacząca w psychologicznej wiedzy o rozwoju religijności człowieka.

Specyfika rozwoju oraz cechy religijności dziecka w wieku poniemowlęcym, przedszkolnym i wczesnoszkolnym

Czesław Walesa pisze: „Nawiązanie świadomej i dobrowolnej relacji z Bogiem powoduje przewrót i największy przełom w biegu ludzkiego bytowania: pojawia się wtedy Inne. U niektórych ludzi dokonuje się to już w okresie małego dziecka (2 i 3 r.ż.). Zjawiska, które składają się na początki właściwej religijności są [...] życiowo doniosłe"

Kim jest więc „mały odbiorca kazań”? Kim on jest jako podmiot aktywny, działający i poznający? To człowiek w zasadniczo w dwóch okresach życia - przedszkolnym i wczesnoszkolnym, choć nierzadko spotyka się także młodszych uczestników liturgii dziecięcych - dzieci w 2 i 3 roku życia.

Specyfika rozwojowa funkcjonowania poznawczego dziecka przekształcającego się w dorastającego (wraz z jego zasadniczymi dyspozycjami psychicznymi w kontakcie w rzeczywistością)

\footnotetext{
3 Cz. Walesa, Rozwój religijności człowieka, dz. cyt., s. 13.

${ }_{4}$ Cz. Walesa, Rozwój religijności człowieka, dz. cyt., s. 170.
} 
to droga - w rozumieniu piagetowskim ${ }^{5}$ - od doświadczeń fizycznych, a także doświadczenia stanów rzeczy i ich przekształceń do ich uwewnętrznienia w formie naiwnego symbolu i naiwnego przekształcania do stopniowej obiektywizacji myślenia najpierw przez konkret (którym jest tak rzecz, jak i przekształcenie), by wreszcie dojść do stopniowego abstrahowania rzeczy, zjawisk i przekształceń ${ }^{6}$. Drogę tę przechodzi dziecko także w zakresie rodzącej się aktywności religijnej.

I tak: w okresie wczesnego dzieciństwa (2 i 3 r.ż.) dziecko kształtuje swoją religijność głównie poprzez uczestniczenie w aktywności religijnej osób znaczących w jego życiu, zazwyczaj rodziców. Istotna jest tu liczba doświadczeń religijnych (zamierzonych i niezamierzonych) oraz zachęcająca postawa osób dla dziecka ważnych. Rozwój poszczególnych sprawności podporządkowany jest przede wszystkim celom i regułom interakcji międzyludzkich - one stanowią podstawową płaszczyznę doświadczania i idącego za nim konstruowania i nabywania. Uczuciowe i poznawcze odzwierciedlanie niektórych sytuacji społecznych rodzi pierwsze oceny wartościujące (początki różnicowania dobra i zła), co daje podsatwę do regulacji wewnętrznych. Bardzo znaczącym mechanizmem jest podążanie za dorosłym, dlatego istotna jest tu liczba i jakość doświadczeń jako „bezpośredniego materiału” do naśladowania. Od tego bowiem zależy to, co dziecko będzie nabywać i przetwarzać poznawczo, a co za tym idzie - przekształcać w nowe formy aktywności. Szybki postęp w rozwoju uczuciowości dziecka

5 J. Piaget, B. Inhelder, Psychologia dziecka, Warszawa 1993.

6 Psychologiczne portrety człowieka. Praktyczna psychologia rozwojowa, red. A. Brzezińska, Gdańsk 2005; Psychologia rozwoju człowieka. Rozwój funkcji psychicznych, red. B. Harwas-Napierała, J. Trempała, Warszawa 2003; S.J. Turner, D.B. Helms, Rozwój człowieka, Warszawa 1999. 
powoduje narastanie potrzeby kontaktów społecznych i nawiązywania więzi, które zwrotnie pobudzać będą rozwój potrzeb, tendencji i uczuć. W wychowaniu religijnym szczególnego znaczenia nabiera podtrzymywanie pierwszych konstrukcji w ramach aktywności religijnej, głównie modlitwy (rozumianej jako zwracanie się do Boga) - dorosły pełni tu funkcję nie tylko wzoru do naśladowania, ale przede wszystkim funkcję „wspomagającego" aktywność własną dziecka. Optymalnym tego kształtem jest takie wspomaganie, jakie pozwala dziecku czuć się autorem i samodzielnym wykonawcą danej czynności. Pamiętać należy, że małe dziecko ma naturalną i mocno zarysowaną tendencję do "podążania za dorosłym”, a w konsekwencji do naśladowania i partycypacji w jego aktywności, w tym także w jego aktywności religijnej. Mechanizm uczenia społecznego odgrywa więc w tym okresie kluczową rolę w rozwoju religijności.

Samo zaś przystosowanie poznawcze do rzeczywistości religijnej odbywa się głównie w zabawie tematycznej - w tym przypadku w zabawie religijnej (dzieje się to na drodze mechanizmów przyswajania i przystosowania do kreowanej w zabawie rzeczywistości). Zabawa (a więc aktywność własna na przyswajanych treściach czy wzorcach zachowań) pozwala na kształtowanie się odpowiednich konstruktów poznawczych (zgodnie z zasadą, że nic, co nie zostało objęte działaniem, nie może się znaleźć w umyśle). Generalnie można więc przyjąć ogólny wniosek, że małe dziecko, by móc coś poznać i zrozumieć, musi działać. Oczywiście owo działanie (a co za tym idzie rozumienie) pozostaje na właściwym mu poziomie rozwojowym, tzn. angażuje rodzaje aktywności typowe dla wieku: głównie zabawę, zadawanie pytań, naśladownictwo, współuczestnictwo w czynnościach dorosłych itp. Efektem poznawczym staje się symbolizacja rzeczywistości (pojawiają 
się pierwsze uogólnienia i pojęcia), która prowadzi do stopniowego nabywania znaczeń i rozumienia symboli religijnych?

W okresie przedszkolnym (3,5-6,5 r.ż.) wchodzimy w tzw. okres religijności magicznej (której jednak nie należy utożsamiać z religijnością ludów pierwotnych - religijność człowieka pierwotnego jest jakością odrębną). Określenie tego okresu w rozwoju religijności mianem „magicznego” wynika raczej z właściwego wtedy dziecku naiwnego sposobu ujmowania i uzasadniania otaczającej je rzeczywistości i zjawisk (naiwno-infantylne sposoby ujmowania i przekształcania rzeczywistości, jej wyjaśniania i uzasadniania, synkretyzm, animizm, antropomorfizm, artyficjalizm, jednokierunkowość i nieodwracalność myślenia, prymitywny realizm, zatarte granice miedzy realnością a fikcją i wyobraźnią, znacząca rola autorytetów i własnego doświadczenia w uzasadnianiu rzeczywistości).

Niemniej dzięki posługiwaniu się symbolami w rozumowaniu (chodzi o symboliczne znaczenia przedmiotów i czynności, a więc o subiektywnie tworzone znaczenia stopniowo separowane od desygnatów) zachodzi o wiele łatwiejsza interioryzacja, a co za tym idzie - intelektualizacja wszelkiej aktywności. Ułatwia to też gromadzenie coraz większych zasobów doświadczeń. Około 5 r.ż. mogą pojawiać się elementarne formy (konkretnego, a czasem nawet formalnego) logicznego myślenia, wnioskowania, ujmowania relacji przyczynowo-skutkowych oraz antycypowania skutków działań własnych. Utrudnieniem (zwłaszcza w przyjmowaniu perspektywy drugiego) jest jednak nadal obecny egocentryzm poznawczy. Zasadniczym osiągnięciem tego okresu jest ukształtowanie zaczątkowego, ale kompletnego obrazu świata i obrazu własnego „ja”, pojawiają się i rozwijają uczucia moralne, społeczne, estetyczne

7 Cz. Walesa, Rozwój religijności człowieka, dz. cyt., s. 170-172. 
i religijne, zwiększa się kontrola nad własnym zachowaniem oraz modelowanie własnego zachowania stosowanie do sytuacji. Dziecko przedszkolne zasadniczo nie jest jednak zdolne do pełnego pojęciowego, logicznego i obiektywnego ujęcia otaczającej je rzeczywistości. Ujmuje ją na swój sposób, w całościach zabarwionych uczuciowo i specyficznie znaczących. W rozwoju poznania nadal istotna jest rola doświadczenia i kontekstu interakcyjnego. Mówiąc językiem praktyki - to, co dziecko przyswaja, ma charakter subiektywny i niekontrolowany przez dziecko - kontrolować może to raczej dorosły, stanowiący "upośrednienie” pomiędzy dzieckiem a otaczającą je rzeczywistością. Walesa podkreśla tu kluczowe znaczenie doświadczenia - w nauczaniu werbalnym religii dziecko w pełni może przyjąć tylko to, co zostało przez nie doświadczone w kontaktach z innymi osobami znaczącymi ${ }^{8}$.

Wymienione cechy myślenia dziecka nie mają być jednak powielane w przekazie, ale raczej uwzględnianie przy antycypowaniu jego subiektywnej perspektywy poznawczej (czyli jego odbioru homilii bądź kazania) z obowiązkowym uwzględnieniem wspomnianego już działania/aktywności własnej, a rozumianego jako konieczne w przypadku dziecka upośrednienie w poznawaniu. W tym miejscu dobrze odwołać się do jednego z przykładów wspaniałej metodyki kaznodziejskiej (którą doświadczenie psychologiczne pozwala traktować jako funkcje osobniczych predyspozycji i wręcz talentu kaznodziejskiego, a nie jako efektu wyuczonego rzemiosła). Przywoływane kazanie ${ }^{9}$ kierowane było do dzieci przedszkolnych

\footnotetext{
8 Cz. Walesa, Rozwój religijności człowieka, dz. cyt., s. 173-219.

9 Przykładem jest homilia o. dra Przemysława Platy, jednego z dwóch homilistów, na których powołuje się autorka niniejszego opracowania. Homilia została wygłoszona w kościele św. Katarzyny w Krakowie (autorka artykułu otrzymała ustną zgodę o. Platy na podanie tego przykładu).
} 
i wczesnoszkolnych, a jego tematem było nawrócenie. Kaznodzieja pojawił się w grupie dzieci z "materiałem poglądowym”, który stanowiły: szklanka zabrudzonej błotem wody, rurka do picia oraz karton z sokiem owocowym. Kaznodzieja zaczął zastanawiać się wraz z dziećmi, w jaki sposób można napić się soku, skoro jedynym naczyniem, do którego można go nalać, jest szklanka z brudną wodą. Może można wlać sok obok brudnej wody i szybko wysączyć go rurką? Nie. Może wlać go do szklanki i zamieszać, a wtedy nie będzie widać brudnej wody? Też nie, bo brud zostanie w soku. To może wylać brudna wodę i nalać soku do szklanki? I to nie, bo przecież szklanka jest brudna. Co więc pozostaje? Tylko dokładne wymycie szklanki i dopiero wtedy można nalać tam soku i go wypić. Jak widzimy, porównanie jest bardzo czytelne - nie można umieścić czegoś nowego i wartościowego (soku - Bożej nauki i Łaski) w czymś zabrudzonym (w sercu zabrudzonym grzechem). Naczynie należy dokładnie oczyścić - nie wchodzą w rachubę żadne środki pośrednie i tylko maskujące „zabrudzenie”. Oczyszczenie musi być całkowite (żal za grzechy, poprawa, sakrament pokuty) - wtedy dopiero „sok” będzie mógł działać dla zdrowia dziecka. Powyższy przykład zwraca uwagę trafną poglądowością odnosząca się do konkretnego doświadczenia i działania dziecka. Poprzez antycypację własnego działania w prezentowanej sy tuacji umożliwił samodzielne wnioskowanie - samodzielne uzasadnianie, a w efekcie pewność nowo nabytego przekonania. Dowodem na pełną internalizację (zrozumienie) nowych treści jest możliwość ich swobodnego przekształcania, czyli np. odpowiadania na tzw. podchwytliwe pytania sprawdzające, na które - po wysłuchaniu (choć lepiej powiedzieć po a ktywnym uczestnictwie w kazaniu) - dzieci odpowiadały zadowalająco.

Dodatkowym atrybutem kazania był jego język - dziecko otrzymywało przekaz słowny na poziomie mu dostępnym 
(proste zdania, proste pytania), ale jednak podawany z poziomu języka człowieka dorosłego. Kaznodzieja zawarł tu wszystkie zamierzone treści bez „zniżania” się do języka dziecka. Pamiętać bowiem należy, że dziecko, choć spontanicznie nie konstruuje wypowiedzi na poziomie wyższym niż aktualny poziom jego rozwoju poznawczego, to jednak dzięki odbiorowi kontekstowemu (kontekst własnego doświadczenia i działania) odbiera i rozumie znaczenia, których samodzielnie jeszcze nie używa. Dotyczy to zwłaszcza pojęć abstrakcyjnych (przyswajanych w kontekście zrozumiałego dla dziecka doświadczenia - dziecko nie poda ich definicji, ale dobrze zilustruje znaczenie przykładem). Stąd więc wymóg nieinfantylizowania wypowiedzi kierowanych do dzieci, a raczej podawania ich w sposób umożliwiający zrozumienie znaczeń na poziomie dostępnym dziecku (zrozumienie niekoniecznie musi być pełne, ważne, by było zgodne z prawdą). Poza tym, znając moc autorytetu, który jest bardzo mocnym „uzasadniaczem” przekonania dziecka, czasem po prostu wystarczy jako argumentu użyć stwierdzenia: nie wiem dlaczego, ale wiem, że tak jest (np. skoro Pan Bóg to dopuszcza, to na pewno jest w tym coś ważnego, dobrego i mądrego; albo po prostu: wierzę $\mathrm{Mu}$, że tak ma być). Uzasadnieniem jest wtedy pewność autorytetu/osoby znaczącej i najprawdopodobniej przełoży się ona na pewność dziecka. Czasem jest to jedyny sposób dla dorosłego, np. wtedy, gdy dziecko żąda rozumnych uzasadnienia niektórych prawd wiary lub zjawisk życia: Dlaczego Bóg nie niszczy od razu całego zła na świecie? Przecież jest wszechmocny. Dlaczego dzieci muszą cierpieć? Ta strategia ułatwia też stosowanie bardzo mądrej zasady wychowywania ${ }^{10}$ (i to nie tylko religijnego): nigdy nie ucz tego, co kiedyś będziesz musiat odwołać.

1o Cz. Walesa, Rozwój religijności człowieka, dz. cyt., s. 285. 
I w końcu cechy rozwoju dziecka w młodszym wieku szkolnym (7-11 r.ż.), w okresie religijności autorytarno-prawnej. Okres ten wyróżnia się stopniowym pojawieniem się logiki, niemniej myślenie przebiega oparte na konkrecie, jest algorytmiczne, jednoznaczne, obowiązujące, uzasadnione czymś możliwym do sprawdzenia przez dziecko lub przez dostępne mu metody weryfikacji. Dziecko ma jeszcze trudność w konfrontacji wielu aspektów zjawiska, np. w rozumowaniu moralnym nie uwzględnia jednocześnie rozmiaru szkody i intencji sprawcy - rozmiar szkody jest tu jedynym kryterium oceny moralnej czynu. Zasady i normy funkcjonują jak prawa przyrody - są wrośnięte w rzeczywistość, a nie wynikają z konwencji lub wolnego wyboru. Niemniej pod koniec tego okresu dziecko zaczyna mieć ukształtowaną względnie obiektywną wizję rzeczywistości. Przy wystąpieniu korzystnych wpływów jego religijność może wyzbywać się prymitywnego antropomorfizmu i magicznych interpretacji. Relacja z Bogiem zaczyna stawać się coraz bardziej rozumna i osobowa, a co za tym idzie - w rozwoju osobniczym mogą pojawiać się sytuacyjnie uwarunkowane dezintegracje, powodowane np. niezwykłymi doświadczeniami religijnymi. Kontekst doświadczenia osobniczego i doświadczeń interpersonalnych ma nadal istotne znaczenie ${ }^{11}$.

\section{Dziecko jako uczestnik życia religijnego i jako odbiorca treści religijnych}

Uwzględniając prawidłowości rozwoju religijności człowieka, możemy ponowić postawione wcześniej pytanie: czy zasadniczym wymogiem psychologicznym stawianym homiliom

${ }^{11}$ Cz. Walesa, Rozwój religijności człowieka, dz. cyt., s. 221-28o. 
i kazaniom dla dzieci jest wyłącznie formalne dostosowanie języka do okresu rozwojowego małego odbiorcy? Najpewniej nie, bo chodzi tu nie tyle o przekaz informacji i wiedzy, co raczej o formację, a to w przypadku dziecka wykracza poza prosty przekaz językowy. Powyższe dane i uwagi umożliwiają sformułowanie następujących uwag i wskazań, które wydają się w tym względzie szczególnie istotne:

- opracowując homilie bądź kazanie dla dzieci, winno się zadbać o odniesienie do kontekstu doświadczenia dziecka, bowiem specyfikę odbioru treści religijnych w przekazie słownym określa fakt, iż dziecko doświadcza synkretycznie, a więc patrzy i odbiera całościowo, włącznie z przekazem pozawerbalnym, czyli np. łączy osobowość z narracją zachowanie kaznodziei jest więc wzmocnieniem (a czasem nawet i przykładem) głoszonych treści;

- dziecko zasadniczo odbiera nie tyle tradycyjnie rozumiane kazanie czy homilię, co raczej konkretną opowieść, będącą rodzajem narracji zespojonej z osobą mówcy i o dużym ładunku autentyzmu. Tym sposobem kaznodzieja nie może być wyłącznie przekazującym informacje, napomnienia czy nakazy. Kaznodzieja w odbiorze dziecka jest „świadkiem” wygłaszanych treści i nierzadko ich przedstawicielem czy nawet ekspertem;

- w przypadku kazań czy homilii dialogowanych przekaz winien uprzedzać wnioskowanie dziecka, a nie wyłącznie oczekiwać samodzielnego poprawnego wnioskowania czy udzielania oczekiwanych odpowiedzi. Przez poprawne naprowadzanie dziecka i doprowadzenie do samodzielnego wniosku jego treść staje się już treścią dziecka, bo została przez nie wypracowana (dziecko ma poczucie jego autorstwa). Pamiętać należy, że antycypacja wnioskowania dziecka to nie to samo, co stopniowe przybliżanie prawidłowej 
odpowiedzi (bo tu niekoniecznie możemy liczyć na własne uzasadnienia, a więc tym samym pewność przekonania);

- dziecko, odbierając całościowo, w pierwszym rzędzie będzie łączyć poznawane treści z osobą mówcy. Język przekazu to też język pozawerbalny, kontekst emocjonalny, siła przekonania, że głoszone treści są dobre i „własne”, że mówca dzieli się nimi jako czymś dla siebie samego szczególnym i wartościowym, a nie tylko je po prostu przekazuje;

- jak już wcześniej wspomniano, szczególne znaczenie $\mathrm{w}$ doświadczeniu religijnym mają dynamizmy: pod zi ela nia, w zajem ności oraz partyc y pacji wżyciu religijnym najbliższego otoczenia. Ich regulacyjna funkcja polega na wzmacnianiu i czynieniu zrozumiałymi głoszonych treści poprzez odwołanie się do doświadczenia dziecka, do faktów i zjawisk jemu znanych. Dziecko poprzez partyc y p a ję nie tyle tworzy własne życie religijne, co raczej w nim uczestniczy i je podziela - rola osób znaczących i autorytetów jest tu nie do przecenienia. Dobrze więc, by odbiór przekazu treści religijnych był dla dziecka doświadczeniem społecznym, w którym się współuczestniczy i które można potem w życiu przetwarzać, a także się nim dzielić.

\section{Cechy dobrego kaznodziei - próba penetracji przyczyn ich skuteczności i popularności}

Przykładów dobrych i skutecznych kazań i homilii dla dzieci jest wiele, co nie znaczy, że jest to zjawisko powszechne. Dzieje się tak najpewniej dlatego, że kazań i homilii dla dzieci dotyczy ta sama zasada, którą odnosimy (z uśmiechem) do każdej innej formy twórczości dla dzieci: trzeba to robić wtaściwie z takim samym zaangażowaniem jak wobec dorostych, tylko że lepiej. 
I są tacy, którzy naprawdę lepiej to robią. W czym tkwi owo „lepiej”? Jakie są tego przyczyny? Nie wydaje się, by można je było łatwo spenetrować, opisać i wyjaśnić - obserwując jednakże kaznodziejów uznanych za bardzo dobrych, można pokusić się o wskazanie tych obserwowalnych ich cech, które najpewniej są przyczynami ich popularności i skuteczności. Na użytek przeprowadzanej oceny obserwacyjnej przyjęto dwa poziomy: ocenę dorosłego i ocenę dziecka. W tym drugim przypadku obserwowano po prostu zachowanie dzieci w trakcie kazania - w przypadku „dobrego” kazania zachowanie dzieci zdecydowanie odbiegało in plus od zachowania podczas pozostałych kazań, a w późniejszej rozmowie dzieci potrafiły powtórzyć i skomentować zasadnicze tezy z przekazywanych treści i oceniały je jako dobre, ważne, mądre, prawdziwe. Oto kilka z zaobserwowanych cech dobrych mówców dziecięcych ${ }^{12}$ :

- umiejętność „mówienia do dzieci”. Dawało się odczuć coś, co wykraczało poza formalne przygotowanie (o ile wiadomo, kaznodzieje ci nie mieli pełnego wykształcenia psychologicznego, a sposób ich mówienia i przekazu zdawał się uwzględniać całą powyższą wiedzę psychologiczną). Z ich cech wewnętrznych przebijały przede wszystkim intuicja i zdolność wczuwania się, łatwość wchodzenia w perspektywę dziecka, pozytywne nastawienie względem rzeczywistości, swoboda w obcowaniu z drugim przy jednoczesnej pokorze, brak dystansu, gotowość komunikacyjna i narracyjna, łatwość dzielenia się, i to z wyraźną przyjemnością. Mówca zawsze sprawiał wrażenie, że słuchacz jest dla niego ważny;

\footnotetext{
12 Autorka uzyskała ustną zgodę dwóch homilistów na powoływanie się na ich przykłady. Drugim jest o. Edward Konkol, werbista z Białegostoku, założyciel Stowarzyszenia Pomocy Rodzinie „Droga”.
} 
- język nie sztucznie dziecięcy, a prosty i zrozumiały (proste zdania, mało dygresji, klarowność i uporządkowanie wątków, tłumaczenie trudniejszych terminów i pojęć abstrakcyjnych zawsze w odniesieniu do doświadczenia dziecka). Wypowiedzi zabarwione adekwatnymi emocjami, ale w sposób autentyczny, a nie sztucznie teatralny lub wystudiowany;

- kazania pozbawione charakteru oceniająco-nakazującego, wyrzutu bądź nawet nagany, a reprezentujące raczej postawę autentycznego zachwytu i płynącej stąd zachęty. Zachęta ta odnosiła się nierzadko do podjęcia czegoś niełatwego lub do realizacji jakiegoś trudnego nakazu, była jednakże zawsze w swym wydźwięku ostatecznie krzepiąca i optymistyczna;

- w kazaniach dialogowanych zauważalna przewaga pomocy i wsparcia w dochodzeniu do wniosków, a nie proste odpytywanie;

- pozytywne cechy kaznodziei widoczne były podczas całej liturgii, a nie tylko w czasie kazania;

- z cech pozapsychologicznych - charyzma w rozumieniu i tłumaczeniu treści religijnych. Kaznodzieja dawał odczuć, ze mówi o czymś, w co gorąco wierzy i czego osobiście doświadcza, a nie tylko to po prostu wie. Dalej: mówienie o Bogu jak o Kimś Bliskim, którego dobrego działania po prostu się doświadczyło i komu jest się za to wdzięcznym głęboką lojalnością dziecka;

- siła przekazu tkwiła raczej w treści, a nie w ekspresji i dodatkowych środkach wzmacniających przekaz, raczej w prezentowanej postawie własnej, a nie w postawie deklarowanej lub nakazywanej;

- na przykładzie kaznodziei możliwe było doświadczenie pozytywnych, a trudnych postaw religijnych (np. postawy autentycznej ufności w sytuacjach trudnych). 
Ponieważ powyższe cechy odnoszą się nie tyle do możliwych do nabycia metodycznych umiejętności warsztatowych, co raczej do cech osobowościowych mówcy (a nie każdy je przecież posiada), dlatego warty uwagi wydaje się postulat, by kaznodzieja, mając własne rozeznanie, miał także możliwość rzetelnej oceny własnych kompetencji w tym względzie, a co za tym idzie, miał również prawo wyboru rodzaju podejmowanej posługi kaznodziejskiej.

\section{Bibliografia}

Piaget J., Inhelder B., Psychologia dziecka, Warszawa 1993.

Przetacznik-Gierowska M., Tyszkowa M., Psychologia rozwoju człowieka. Zagadnienia ogólne, Warszawa 1996.

Psychologia rozwoju człowieka. Charakterystyka okresów życia, red.

B. Harwas-Napierała, J. Trempała, Warszawa 2004.

Psychologiczne portrety człowieka. Praktyczna psychologia rozwojowa, red. A. Brzezińska, Gdańsk 2005.

Turner S.J., Helms D.B., Rozwój człowieka, Warszawa 1999.

Walesa Cz., Rozwój religijności człowieka, t. 1: Dziecko, Lublin 2005. 